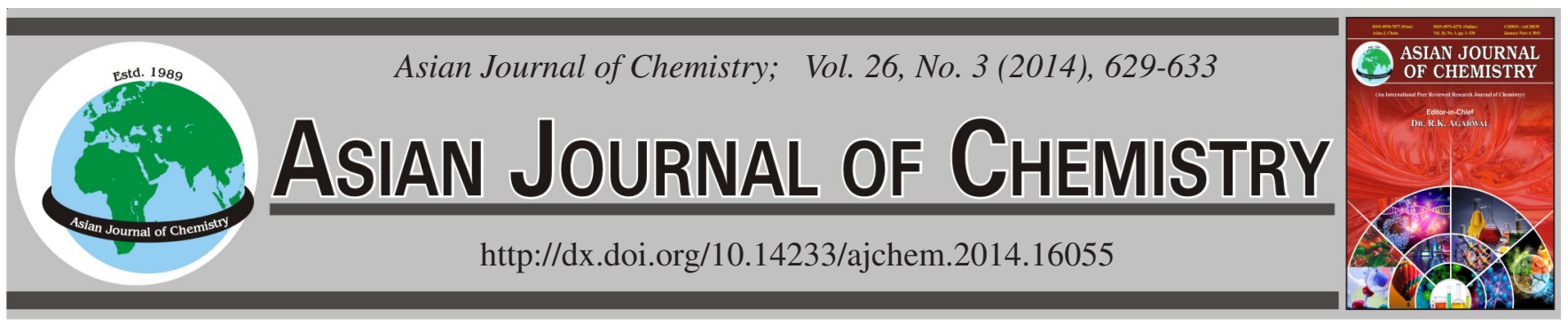

\title{
REVIEW
}

\section{Cationic Polyacrylamide: Synthesis and Application in Sludge Dewatering Treatment}

\author{
ZHENZHEN JIANG ${ }^{1}$ and JUNREN ZHU ${ }^{2, *}$
}

${ }^{1}$ Chongqing Vocational Institute of Engineering, Chongqing 400037, P.R. China

${ }^{2}$ Chongqing City Management College, Chongqing 401331, P.R. China

*Corresponding author: Tel: +86 23 63311221; E-mail: zhujunren008@163.com

\begin{abstract}
Cationic polyacrylamide (CPAM) were used extensively in water treatment, enhanced oil recovery and sludge dewatering. The review summarized the synthesis methods research progress of cationic flocculants. Four groups of synthesis technologies of cationic copolymers were reviewed, including aqueous solution polymerization, dispersion polymerization, inverse emulsion polymerization and photo initiated polymerization. Furthermore, the paper reviewed that the application of cationic flocculants in sludge dewatering treatment. Based on these reviews, the future research perspectives of synthesis and application on cationic flocculants in sludge dewatering treatment were proposed.
\end{abstract}

Keywords: Cationic polyacrylamide, Synthesis, Sludge dewatering treatment, Flocculants.

\section{INTRODUCTION}

Cationic polyacrylamide (CPAM) were used extensively in water treatment, enhanced oil recovery and sludge dewatering ${ }^{1}$. Cationic polyacrylamide were an important flocculant with high molecular weight and electropositivity which contains cationic functional groups such as acryloxyethyltrimethyl ammonium chloride (DAC), methacryloxyethyltrimethyl ammonium chloride (DMC), dimethyldiallyammonium chloride (DMDAAC), etc. ${ }^{2,3}$. These kinds of cationic polyacrylamide with higher molecular weight and charge became the most important flocculants. Cationic polyacrylamide with high molecular weight could produce more stretching molecular chain in the water which will increase the capacity of adsorption and bridge for suspended particles flocculation. Moreover, the residual negative charge was balanced by cations between the chains which also served to hold the chains together ${ }^{4}$. The mainly interaction mechanism between CPAM and suspended particles were static electricity, hydrogen bonding, covalent bond and van der Waals force ${ }^{5}$. Base on these mechanism, the length of the chains mainly determined flocculation performance. Because of the differences in the length of the chains, the molecular weight of a polymer is determined on a statistical basis $^{6}$. Accordingly, how to obtain the higher molecular weight and higher solubility property of CPAM was the most critical point in the polymerization.

Aqueous solution polymerization ${ }^{7}$, dispersion polymerization $^{8}$, inverse emulsion polymerization ${ }^{9}$ and photo initiated polymerization ${ }^{10}$ were the most mainly four kinds of CPAM synthesis technologies at present. The present review article attempts to survey the synthesis technology of CPAM, it could be found that a detailed analysis and review of past academic research progress could be valuable with the rapid development of synthesis technology. Then the fundamental aspects of these synthesis technologies were analyzed and summarized. The developments in sludge dewatering applications were also reviewed and discussed. Finally, the main conclusions and future perspectives were proposed.

Synthesis methods of CPAM: Moureu first prepared polyacrylamide using acryloyl chloride and ammonia in the low temperature in the lab in 1893. But Americans had took the lead in realizing the industrialization production using sulphuric acid aqueous solution polymerization until 1954. However, in the 1970s, Americans successfully developed cationic polyacrylamide through second generation solution polymerization at the first time. Up to now, synthesis technologies of CPAM had experienced a lot of developments, including free radical copolymerization method, cationic modification of PAM methods and cationic grafting polymerization methods ${ }^{11,12}$. The modification methods could obtain relatively high molecular weight of cationic polyacrylamide polymer, but which had poor stability, short duration and high price ${ }^{13}$. Graft polymerization methods could obtain natural biodegradability of cationic polyacrylamide, but was possible leading to poor stability, short storage time and the low molecular 
weight ${ }^{14}$. Above these two synthesis methods were without using extensively in the industrialization production. The most important CPAM synthesis method was free radical copolymerization method, the basic reaction of polymerization usually expressed as Fig. 1. In recent years, free radical polymerization method included four different synthesis technologies as follows: aqueous solution polymerization, dispersion polymerization, inverse emulsion polymerization and photo initiated polymerization.

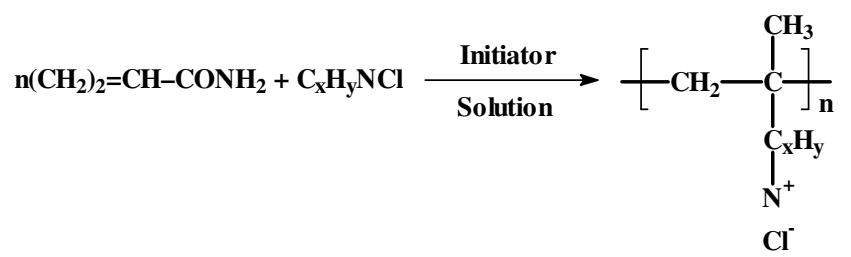

Fig. 1. Basic reaction of CPAM polymerization

Aqueous solution polymerization: Fig. 2 presented the technological process of aqueous solution polymerization. It showed that acrylamide, cationic monomer and initiator dissolving in the water were induced polymerization by adjusting the $\mathrm{pH}$, temperature, time and additives. Finally, CPAM colloid products was obtained.

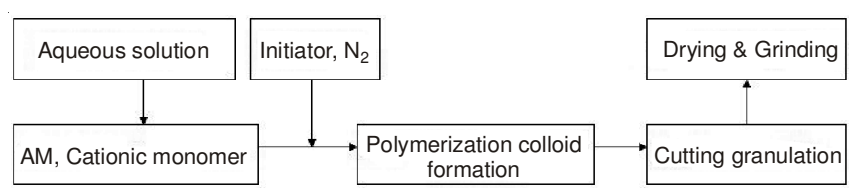

Fig. 2. Technological process of aqueous solution polymerization

The aqueous solution polymerization of CPAM was firstly devlopoed and most commonly method at present. The synthesis technology had the advantages of safety, short production cycle, simple equipment and less environment pollution ${ }^{15}$. It is more important that cationic degree can be easily controlled through copolymerization ${ }^{16}$. Based on the above advantages, this technology was widely used in European and American countries. Table-1 presents the research of aqueous solution polymerization at present.

From previous studies, there was still a problem that reactivity ratio between acrylamide and other monomers have a big difference (For example: $r_{\mathrm{AM}}=1.0, \mathrm{r}_{\mathrm{DMDAAC}}=0.69$ ), which can lead to increase reaction mechanism complicated ${ }^{17,18}$. In this way, it was difficult to acrylamide monomer complete polymerization, CPAM with high purity is very necessary consider for the techology. Due to biotoxicity, the technology of aqueous solution polymerization had been gradually given up in China.

Dispersion polymerization: Fig. 3 presented the technological process of dispersion polymerization. It showed that acrylamide and a double bond of quaternary ammonium dissolving in the saline solution was different from aqueous solution polymerization ${ }^{19,20}$. Finally, the discrete form of small polymer particles were precipitated down.

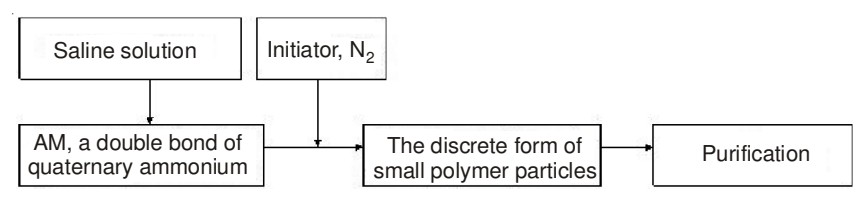

Fig. 3. Technological process of dispersion polymerization

Osmond had first put forward a new method-dispersion polymerization in the 1970s and which was studied in the 1980s and $1990 \mathrm{~s}^{21-23}$. The synthesis technology had the advantages of fast reaction rate, good fluidity and good water solubility. And it is more important that the discrete form of polymer had the unique side chain structures with a high density of positive charge. Based on the above advantages, this technology had been widely studied in china and America. Table-2 presents the research of dispersion polymerization at present.

\begin{tabular}{|c|c|c|c|c|}
\hline \multicolumn{5}{|c|}{$\begin{array}{l}\text { TABLE-1 } \\
\text { AQUEOUS SOLUTION POLYMERIZATION OF CATIONIC POLYACRLAMIDE }\end{array}$} \\
\hline Raw materials & Initiator & Temperature & Results & Ref. \\
\hline $\begin{array}{l}\text { AM, } \\
\text { acrylonitrile }\end{array}$ & 4,4'-azobis-4- cyanovaleric acid & $30-90^{\circ} \mathrm{C}$ & $\begin{array}{l}\text { The dependency of initial polymerization rate on } \\
\text { monomer and initiator concentrations at } 50^{\circ} \mathrm{C} \text { were } \\
1.16 \pm 0.01 \text { and } 0.52 \pm 0.03 \text {, respectively }\end{array}$ & 34 \\
\hline $\begin{array}{l}\text { AM, } \\
\text { DMDAAC }\end{array}$ & $\begin{array}{l}\text { Inorganic: } \mathrm{K}_{2} \mathrm{~S}_{2} \mathrm{O}_{8} \text { and } \mathrm{NaHSO}_{3} \text {, } \\
\text { organic: } 2,2 \text {-azobis ( } 2 \text { - } \\
\text { amidinopropane)-dihydro chloride }\end{array}$ & $\begin{array}{l}\text { Inorganic: } 25-30^{\circ} \mathrm{C} \text {, } \\
\text { organic: } 55-60^{\circ} \mathrm{C}\end{array}$ & $\begin{array}{l}\text { PDA can be obtained higher intrinsic viscosity the } \\
\text { preparation of different cationic degree products } \\
\text { should pay attention to optimizing according to } \\
\text { different monomer ratio. }\end{array}$ & 35 \\
\hline
\end{tabular}

\begin{tabular}{|c|c|c|c|c|c|}
\hline \multicolumn{6}{|c|}{$\begin{array}{c}\text { TABLE-2 } \\
\text { DISPERSION POLYMERIZATION OF CATIONIC POLYACRLAMIDE }\end{array}$} \\
\hline Raw materials & Solution & Initiator & Stabilizer & Results & Ref. \\
\hline AM, DMC & $\begin{array}{c}\left(\mathrm{NH}_{4}\right)_{2} \mathrm{SO}_{4} \\
\text { or NaCl}\end{array}$ & $\begin{array}{l}2,2^{\prime} \text {-azobis [2-(2-inidazolin-2-yl) } \\
\text { propane]- dihydro chloride (VA- } \\
044)\end{array}$ & $\begin{array}{l}\text { Poly(acryloylxyethyl } \\
\text { trimethyl ammonium } \\
\text { chloride) (PDAC) }\end{array}$ & $\begin{array}{l}\text { Varying the salt concentration could } \\
\text { affect the morphology and } \\
\text { molecular weight of the resultant } \\
\text { copolymer particles significantly. }\end{array}$ & 36 \\
\hline $\begin{array}{l}\text { AM, } \\
\text { AODBAC }\end{array}$ & $\left(\mathrm{NH}_{4}\right)_{2} \mathrm{SO}_{4}$ & $\begin{array}{l}2,2 \text {-azobis(2-methyl } \\
\text { propionamidine) dihydrochloride } \\
\text { (AIBA) }\end{array}$ & $\begin{array}{l}\text { Poly(acryloyloxyethyl } \\
\text { trimethyl ammonium } \\
\text { chloride) (PAOTAC) }\end{array}$ & $\begin{array}{l}\text { The product particle size range of } 4 \text { - } \\
7 \mu \mathrm{m} \text { are more than PAM particle } \\
\text { size through the same method } \\
\text { polymerization. }\end{array}$ & $\begin{array}{l}37, \\
38\end{array}$ \\
\hline AM, DMC & $\mathrm{NaCl}$ & $\begin{array}{l}\text { 2,2'-azobis (2-amidinopr opane)- } \\
\text { dihydro chloride (V-50) }\end{array}$ & $\begin{array}{l}\text { Poly(dimethylaminoethyl } \\
\text { methacrylate methyl } \\
\text { chloride) (PDMC) }\end{array}$ & $\begin{array}{l}\text { The molecular weight of PDMC } \\
\text { formed was } 1.5 \times 10^{5}-7.0 \times 10^{5}\end{array}$ & 39 \\
\hline
\end{tabular}


From previous studies, there were also some shortcomings for this technology. The main problem was that the polymer products were low concentration and poor stability. Moreover, due to high monomer prices, cationic quaternary ammonium salt monomer were not suitable for mass production. Up to now, the technology of dispersion polymerization had an obstacle for large scale application in the industrial production all over the world.

Inverse emulsion polymerization: Fig. 4 presented the technological process of inverse emulsion polymerization. It shows that acrylamide, cationic monomer dissolving in the aqueous solution were added to water-insoluble organic solvent that be conducted in water-in-oil emulsion, inverse emulsion polymerization would be occured in the presence of initiator.

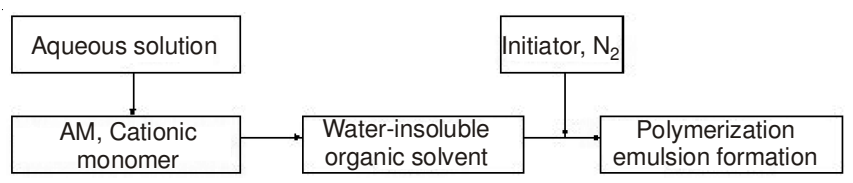

Fig. 4. Technological process of inverse emulsion polymerization

Vanderhoff first proposed inverse emulsion polymerization method in 1962, after inverse emulsion polymerization had become one of the important methods for polymer production ${ }^{24}$. The synthesis technology had easily obtained higher molecular weights and fast reaction rates ${ }^{25}$. Moreover, the chance of implosion in oil phase had been greatly reduced because of the easy control of reaction system ${ }^{26}$. Meanwhile, the range of molecular weight was narrow with the smoothly reaction. Table- 3 presented the research of dispersion polymerization at present.

From previous studies, it was difficult to control emulsification and oil-water separation. Moreover, the operate process was complicated and the equipments utilization ratio was $\operatorname{low}^{27}$. Up to now, the technology of inverse emulsion polymerization was not widely used in China.

Photo initiated polymerization: Fig. 5 presented the technological process of photo initiated polymerization. It showed that acrylamide, cationic monomer dissolving in the water were induced by photo radiation. Finally, CPAM colloid products had been obtained.

Photo initiated polymerization had received more and more attention in recent years. The synthesis technology had many advantages such as simple operation, easy control, height

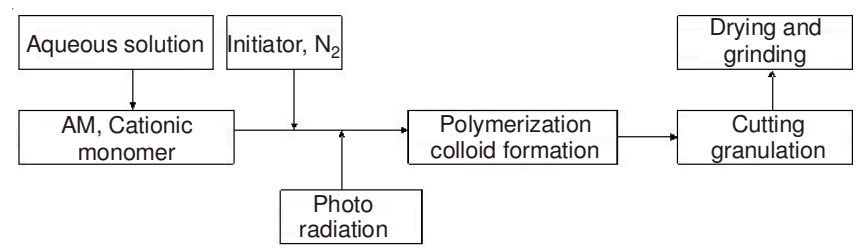

Fig. 5. Technological process of photo initiated polymerization

purity product and less investment. Moreover, low activation energy of reaction could be fastly initiated polymerization at room temperature. The researches of photo initiated polymerization at present were as follows: Seabrook and Gillert ${ }^{28}$ studied that classical free-radical polymerization kinetics provided an acceptable quantitative description for this system, even though the rate of coefficients controlling aqueous-phase polymerization of acrylamide were very sensitive to change in solvency during polymerization. The initiation rates with all three photoinitiators were proportional to the absorption at $254 \mathrm{~nm}$ wavelength of the $\mathrm{Hg}$ lamp ${ }^{28}$. Liu et al. ${ }^{29}$ researched that cationic polyacrylamide $\mathrm{P}(\mathrm{AM}-\mathrm{DMC})$ had been synthesized by the metal halide lamp irradiation. The reaction process was stable and it could obtain good solubility and high molecular weight products. So it was considered that the technology of inverse emulsion polymerization was worthy of study and exploration in actual production.

Application in sludge dewatering treatment: In recent years, CPAM known as sludge dewatering agent, had been used in activated sludge dehydration in municipal wastewater treatment plant, which may remove the water contained in the activated sludge $\mathrm{e}^{30}$. The flocculation mechanism that the surface adsorption water of activated sludge particles was separated out through charge neutralization and adsorption bridging ${ }^{31}$. Fig. 6 showed the mechanism of the sludge dewatering with CPAM. Cationic polyacrylamide could play an important role in sludge dewatering, micro-polluted source water, even industrial water treatment ${ }^{32}$. It showed that the charge neutralization and the adsorption/bridging mechanisms played an important role in sludge dewatering performance.

Table- 4 showed the application situation of CPAM in sludge dewatering treatment. Generally, the organic polymeric sludge dewatering agent was effective application in sludge dewatering treatment, due to characteristics of CPAM with linear molecular chain and positive charge group and large specific surface area. In the process of sludge dewatering treatment, there were only a few dosages in concentrator. Moreover,

\begin{tabular}{|c|c|c|c|c|c|}
\hline \multicolumn{6}{|c|}{$\begin{array}{c}\text { TABLE-3 } \\
\text { RESEARCH ON INVERSE EMULSION POLYMERIZATION OF CATIONIC POLYACRYLAMIDE }\end{array}$} \\
\hline Raw materials & $\begin{array}{l}\text { Temp. } \\
\left({ }^{\circ} \mathrm{C}\right)\end{array}$ & $\begin{array}{l}\text { Initiator and mass } \\
\text { fraction }\end{array}$ & $\begin{array}{l}\text { Mass fraction of } \\
\text { monomer }(\%)\end{array}$ & Results & Ref. \\
\hline AM, MADQUAT & 30 & $\begin{array}{l}\left(\mathrm{NH}_{4}\right)_{2} \mathrm{~S}_{2} \mathrm{O}_{8} / \mathrm{NaHSO}_{3} \\
=2: 1\end{array}$ & 30 & $\begin{array}{l}\text { Greater compressive yield stress was achieved for the } \\
\text { strong flocs produced by copolymer prepared in inverse } \\
\text { microemulsion than produced by that in solution. }\end{array}$ & 40 \\
\hline $\begin{array}{c}\text { AM } \\
\text { Dimethylaminoethyl } \\
\text { acrylate methyl } \\
\text { chloride }\left(\mathrm{Q}_{9}\right)\end{array}$ & 50 & $\begin{array}{l}\text { Ammonium } \\
\text { persulphate (APS) } \\
\text { and } \mathrm{NaHSO}_{3}\end{array}$ & 25 & $\begin{array}{l}\text { The formulations with } 3000 \mathrm{ppm} \text { of initiator were the } \\
\text { most interesting of all copolymer compositions since they } \\
\text { presented very high conversions and their viscosities were } \\
\text { higher than commercial copolymer solutions. }\end{array}$ & 41 \\
\hline AM, DMDAAC & 40 & $\begin{array}{l}\text { Initiator: } m\left(\mathrm{~K}_{2} \mathrm{~S}_{2} \mathrm{O}_{8}\right) / \\
m\left(\mathrm{NaHSO}_{4}\right)=5: 1\end{array}$ & 33 & $\begin{array}{l}\text { While PDA is mixed with alum as flocculating agent, the } \\
\text { optimum dosages for alum and PDA are } 25 \mathrm{mg} / \mathrm{L} \text { and } 4 \text {. } \\
16 \mathrm{mg} / \mathrm{L} \text {. }\end{array}$ & 42 \\
\hline
\end{tabular}


TABLE-4

APPLICATION OF CPAM IN SLUDGE DEWATERING TREATMENT

\begin{tabular}{ccl}
\hline Factory & Reagent dosage $(\mathrm{g} / \mathrm{kg})$ & Effect \\
\hline $\begin{array}{c}\text { Small-scale waste water } \\
\text { treatment plant, Czech }\end{array}$ & Polymer organic flocculant, 8 & $\begin{array}{l}\text { Specific consumption of flocculant amounting to 5.4 g/kg of dry solids of } \\
\text { sludge (calculated value) under identical operational conditions proves to } \\
\text { be the best economical option. }\end{array}$ \\
\hline $\begin{array}{c}\text { Tangjiatuo Wastewater } \\
\text { Treatment Plant, China }\end{array}$ & P(AM-DAC-DMC), 1.0 & $\begin{array}{l}\text { Minimum filter cake moisture content and turbidity of 63.5\% and 2.95 } \\
\text { NTU were achieved. }\end{array}$ \\
\hline $\begin{array}{c}\text { Beijing Wastewater } \\
\text { Treatment Plant, China }\end{array}$ & CPAM CZ-8698, 9.36-15.61 & $\begin{array}{l}\text { Both of fractal dimensions arrived at maximum values }\left(\mathrm{D}_{1}=1.19, \mathrm{D}_{2}=\right. \\
1.41) \text {, at the optimalpolymer dosage which meant that the flocs formed at } \\
\text { this dosage had the coarsest surface and most compact structure. }\end{array}$ \\
\hline
\end{tabular}
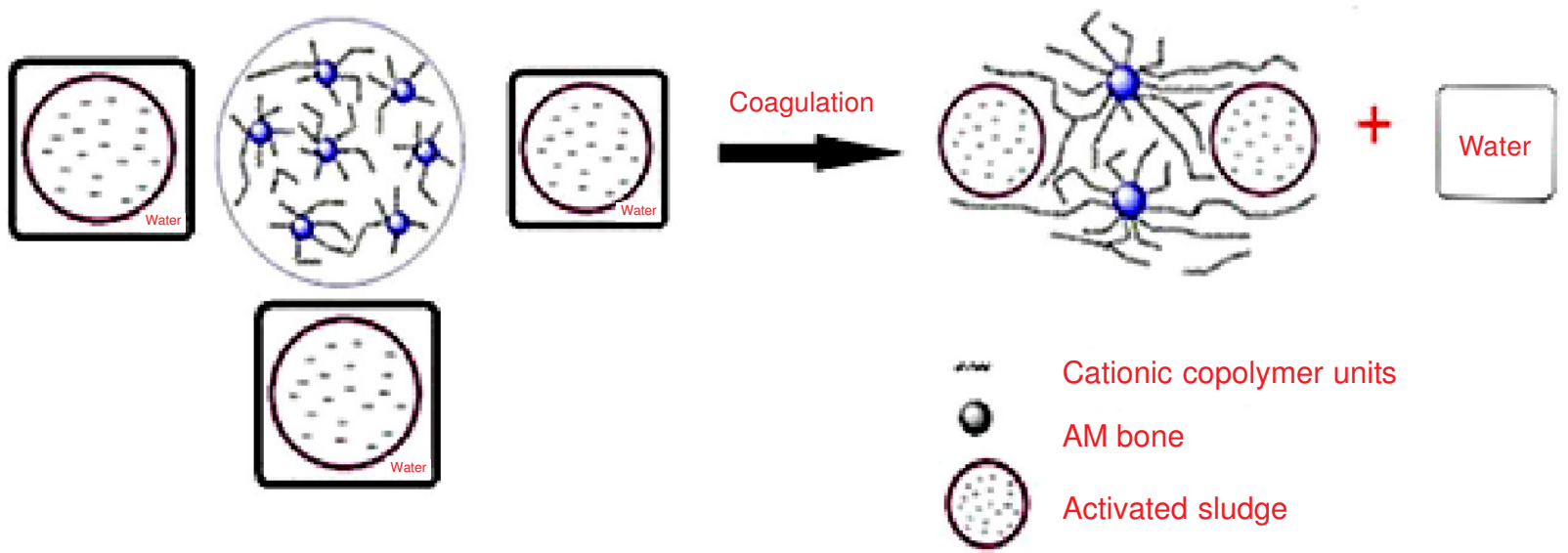

Fig. 6. Mechanism of the sludge dewatering with CPAM

sludge dewatering efficiency by CPAM conditioning was less cost than the other methods such as thermal drying, mechanical pressure and mechanical centrifugation. Meanwhile, CPAM flocculants with non-toxic, free from environment pollution ${ }^{33}$. So the application of dewatering had been attracted more and more attention of the researchers in Wastewater Treatment Plant. However, the next steps would be increasing economic feasibility research to provide technical support for its application.

\section{Conclusion}

Above four synthesis technologies had both weaknesses and strengths, which suitable for CPAM of different sizes. It was that the most development prospects of photo initiated polymerization from a comparison among these synthesis technologies. Moreover, linear molecular chain and positive charge group of CPAM could influence the effect of the sludge dewatering. Therefore, research and development of composite and special CPAM was necessary for the challenge of the sludge dewatering. With the improvements of the industrial production technology, due to higher the quality and lower the cost, CPAM would be used in every fields of water treatment. What's more, improve the conversion rate to reduce the monomer residues should be necessary to make contributions to environmental friendly. Finally, the study of the sludge dewatering mechanism should provide a perfect theoretic basis for practical application. In a word, study on synthesis and application of CPAM in sludge dewatering treatment was positive for the environment, especially for human body health. Synthesis and application of CPAM was endowed with a promising future.

\section{ACKNOWLEDGEMENTS}

The authors are grateful for the financial support provided by Research Foundation for Advanced Talents, Chongqing City Management College (Project No. 2013 kyqd09) and Key Science Program of Chongqing Vocational Institute of Engineering (Project No. KJA201301).

\section{REFERENCES}

1. N. Tekin, A. Dinçer, Ö. Demirbas and M. Alkan, Appl. Clay Sci., 50, 125 (2010).

2. L.J. Wang, J.P. Wang, S.J. Zhang, Y.Z. Chen, S.J. Yuan, G.P. Sheng and H.Q. Yu, Sep. Purif. Technol., 67, 331 (2009).

3. H.L. Zheng, J.R. Zhu, Z.Z. Jiang, F.Y. Ji, M.Z. Tan, Y.J. Sun, S.X. Miao and X.K. Zheng, Adv. Mater. Res., 414, 172 (2012).

4. N. Unwin, J. Mol. Biol., 346, 967 (2005).

5. B.A. Rozenberg and R. Tenne, Prog. Polym. Sci., 33, 40 (2008).

6. R.W.J. Westerhout, J. Waanders, J.A.M. Kuipers and W.P.M. van Swaaij, Ind. Eng. Chem. Res., 36, 1955 (1997).

7. Z.L. Yang, B.Y. Gao, C.X. Li, Q.Y. Yue and B. Liu, Chem. Eng. J., 161, 27 (2010).

8. D. Chen, X. Liua, Y. Yue, W. Zhang and P. Wang, Eur. Polym. J., 42, 1284 (2006).

9. X. Ge, W. Ye, M. Xu and Z. Zhang, Polymer, 39, 1917 (1998).

10. K.H. Hong, N. Liu and G. Sun, Eur. Polym. J., 45, 2443 (2009).

11. S.K. Kogyo Co Ltd, US Patent 55108405 (1980).

12. H.C. Ine, US Patent 62059602 (1987).

13. A. Bhattacharya and B.N. Misra, Prog. Polym. Sci., 29, 767 (2004).

14. K. Kato, E. Uchida, E.T. Kang, Y. Uyama and Y. Ikada, Prog. Polym. Sci., 28, 209 (2003).

15. H.L. Zheng, X. Tang, L.X. Shen, X. Gao, W. Wang and Y.X. You, J. Chongqing Univ., 33, 115 (2010).

16. P. Zhang And B. Ren, Asian J. Chem., 25, 3966 (2013).

17. Y.V. Bune, A.I. Barabanova, Y.S. Bogachev and V.F. Gromov, Eur. Polym. J., 33, 1313 (1997). 
18. I. Rintoul and C. Wandrey, Polymer, 46, 4525 (2005).

19. M.H.R. Fanood and M.H. George, Polymer, 29, 128 (1988).

20. B. Gao, Y. Lv and H. Jiu, Polym. Int., 52, 1468 (2003).

21. M.H. Rafi'ee Fanood and H. Maurice George, Polymer, 29, 128 (1988).

22. Y. Zhang, K. Bi, Y. Xing and Y. Liu, Fine Chem., 24, 592(2007)

23. B. Ray and B.M. Mandal, Langmuir, 13, 2191 (1997).

24. J.W. Vanderhoff, E.B. Bradford, H.L. Tarkowski, J.B. Shaffer and R.M. Wiley, Adv. Chem. Ser., 34, 32 (1962).

25. D. Benda, J. Šnupárek and V. Cermák, Eur. Polym. J., 33, 1345 (1997).

26. D.W. Lim, K.G. Song, K.J. Yoon and S.W. Ko, Eur. Polym. J., 38, 579 (2002).

27. L. Ouyang, L. Wang and F.J. Schork, Polymer, 52, 63 (2011)

28. S.A. Seabrook and R.G. Gilbert, Polymer, 48, 4733(2007).

29. F. Liu, Z. Li and S. Yu, Polym. Mater. Sci. Eng., 26, 22 (2010).

30. B. Jin, B.M. Wilen and P. Lant, Chem. Eng. J., 95, 221 (2003).

31. J.H. Bruus, P.H. Nielsen and K. Keiding, Water Res., 26, 1597 (1992).

32. Y. Qi, K.B. Thapa and A.F.A. Hoadley, Chem. Eng. J., 171, 373 (2011)

33. A. von Homeyer, D.-O. Krentz, W.-M. Kulicke and D. Lerche, Colloid Polym. Sci., 277, 637 (1999)
34. S.M. Xu, L.Q. Cao, R.L. Wu and J. Wang, J. Appl. Polym. Sci., 101, 1995 (2006).

35. E.J. Barrett Keith, Br. Polym. J., 5, 259 (1975).

36. D. Chen, X. Liu, Y. Yue, W. Zhang and P. Wang, Eur. Polym. J., 42, 1284 (2006).

37. B.K. Song, M.S. Cho, K.J. Yoon and D.C. Lee. J. Appl. Polym. Sci., 87, 1101 (2003).

38. M.S. Cho, K.J. Yoon and B.K. Song, J. Appl. Polym. Sci., 83, 1397 (2002).

39. Y.M. Wu, Q.F. Chen, J. Xu and J.M. Bi, J. Appl. Polym. Sci., 108, 134 (2008).

40. Y. Shen, A. Zhang and G. Wu, J. Appl. Polym. Sci., 110, 3889 (2008).

41. I. Inchausti, P.M. Sasia and I. Katime, J. Mater. Sci., 40, 4833 (2005).

42. X. Wang, H. Zhou and Y. Zhang, J. Funct. Polym., 18, 660 (2005).

43. J. Borán, L. Houdková and T. Elsäßer, Resour. Conserv. Recy., 54, 278 (2010).

44. J.R. Zhu, H.L. Zheng, Z.Z. Jiang, Z. Zhang, L.W. Liu, Y.J. Sun and T. Tshukudu, Desalin. Water Treat., 51, 2791 (2013).

45. J. Feng, Y. Wang and M. Yang, Acta Sci. Circumstant., 31, 1421 (2011). 